\title{
Physicochemical and sensory characteristics of snack bars added of jerivá flour (Syagrus romanzoffiana)
}

\author{
Edson Pablo da SILVA ${ }^{1,2^{*}}$, Heloisa Helena SIQUEIRA ${ }^{3}$, Clarissa DAMIANI ${ }^{1}$, \\ Eduardo Valério de Barros VILAS BOAS ${ }^{3}$
}

\begin{abstract}
The objective of this work was to characterize promising fruit crops and to explore opportunities for the sustainable and commercial use of flours obtained from fruits as an ingredient in snack bars. The fruit selected was Jeriva, which grow from north to eastern Brazil, and can be found in the Savanna biome. The fruit flour was obtained from dehydrated pulps and the proximate composition, dietary fiber, vitamin $\mathrm{C}, \%$ scavenging free radicals, mineral composition, $\mathrm{pH}$, ${ }^{\circ} \mathrm{Brix}$, titratable acidity and sensory analysis were determined. The flour was incorporated into the formulation by partial substitution of the standard ingredients of snack bars. The presence of increasing amounts (up to 20\%) of Jeriva fruit flour resulted in sensory accepted snack bars, with 7.02 average in the scores evaluated, without significant differences among the formulations and significantly increased the protein at $7.12 \%$, vitamin C $40.81 \mathrm{mg}^{-\mathrm{g}^{-1}}$ and fiber contentes showed values at $6.66 \%$ for dietary fiber. Moreover, the results of free radical scavenging confirmed the greater antioxidant activity proportional to the increment of flour. Therefore, Jeriva fruit flour could be an alternative sensorily acceptable, for obtaining of snack bars.
\end{abstract}

Keywords: nutritional source; chemical characteristics; fiber content; bioactive compounds; queen palm.

Practical Application: The development of new food products with high added value has become a challenge for the food industry, since the nutritional quality of the same, will depend on the raw material used. Thus, the Savannah fruits become a good option for the food industry, since they present themselves as good sources of bioactive compounds.

\section{Introduction}

In recent years, a significant increase in the consumption of "fast foods" and snacks has been observed as a response to the change in lifestyle of the population. Consumers are looking for easy and fast prepared foods, and ease in the acquisition of pre-prepared, frozen, and ready-to-use products in the market. Among these products, stand out the "snacks", which are defined as small meals, of light or substantial nutritional value, that can be related to the sensory attributes "healthy" and/or "fun". Several products are classified as "snack", among which we can mention the mini-pizzas, cookies, popcorn and cereal bars (Bower \& Whitten, 2000). Cereal bar is a product obtained from the mixture or combination of three or more foods hygienically prepared with specific nutritional values and flavors, added of a bonding ingredient which confers proper texture. These bars are packaged and sold in individual portions of 25 to 30 grams (Izzo \& Niness, 2001).

The tendency to consume more nutritious foods instead of sweets and candies has led to the emergence of various bar types, including variations like chocolate coating or incorporation of different fruits and nuts. Once the consumption of cereals has been expanding beyond breakfast for anytime of the day, these products have become an excellent vehicle for delivering ingredients to functional foods in the marketplace. The cereals have an increasingly vital role in the modern lifestyle because of the convenient forms they can be used, such as ready-to-consume instants, cereal bars and energy bars (Silva et al., 2014).

Energy bars are a dietary supplement often consumed by athletes and other physically active people to maintain their calorific needs (Norajit et al., 2011). People concerned in getting healthier foods and keeping the good body fitness have changed their eating habit which has promoted a growth in the cereal bars market of $20 \%$ per year (Lin et al., 2010). Jerivá (Syagrus romanzoffiana Cham. Glassm) is a palm widely distributed throughout the Brazilian territory, used for landscaping and has the characteristic of producing large amounts of fruits. Scientific studies aiming to disclosure and disseminate knowledge about this native species can provide its sustainable maintenance Studies about the use of jeriva fruit are scarce and no information is available on its chemical, physical and nutritional characteristics. The objective of this study was to characterize the jerivá flour and evaluate its potential use in the development of snack bars.

\section{Materials and methods}

Jerivá fruit (Syagrus romanzoffiana Cham Glassm) were harvested in an area of native "Brazilian Savanna" on the Southern of Minas Gerais State, Brazil. Ingredients were purchased in local market. Reagents were of analytical grade. 


\subsection{Obtainning of jerivá flour}

Fruits were washed and sanitized in $1.216 \mu \mathrm{M}$ sodium hypochlorite solution for the removal of field dirt and impurities. Pulp was separated from the seed using a depulper (Hauber Macanuda model MJI-05, series 074-09 Joinvile - SC- Brazil). Pulps were dehydrated at $65{ }^{\circ} \mathrm{C}$ for $48 \mathrm{~h}$ and then ground in industrial miller (model LN32 series 40/12 Joinvile - SC-Brazil), using a common sieve mash 3 for the separation of larger particles to obtain the flour. The flour was stored at $-18^{\circ} \mathrm{C}$ until the processing of snack bars.

\subsection{Processing of snack bars}

The production of snack bars was carried out in the Department of Food Science of the Federal University of Lavras - Brazil. The technology used in the formulation of food bars was previously reported by Silva et al. (2014). The snack bar recipes consisted in $400 \mathrm{~g}$ of crushed corn starch biscuit, $60 \mathrm{~g}$ of oat, $60 \mathrm{~g}$ of skimmed milk powder, $40 \mathrm{~g}$ of rice flakes, $450 \mathrm{~g}$ of corn syrup. When present, part of crushed biscuit was replaced by increasing amounts of jerivá flour (5\%, 10\% 15\% and $20 \%$ - crushed biscuit + jerivá flour: $380 \mathrm{~g}+20 \mathrm{~g} ; 360 \mathrm{~g}$ $+40 \mathrm{~g} ; 340 \mathrm{~g}+60 \mathrm{~g}$ and $320 \mathrm{~g}+80 \mathrm{~g})$. Hereafter, the level of jerivá flour in the supplemented bars will be referred as CCO followed by the percentage of this ingredient.

The dry ingredients (corn starch biscuit, skimmed milk powder, rice flakes, oat flakes) were mixed in a stainless steel tray, using a teaspoon. Simultaneously, the binding syrup was prepared by mixing corn glucose and honey without heating. The syrup was added to the solids blend and homogenized. The mixture was laminated $(1 \mathrm{~cm})$, left to stand for $8 \mathrm{~h}$ and then cut (10 x $2 \mathrm{~cm}$, approximately $25 \mathrm{~g}$ each), packed in aluminum-coated cellophane and maintained at $20{ }^{\circ} \mathrm{C}$ until further analysis.

\subsection{Physico-chemical analysis}

The water activity (Aw) of crushed bars was measured in AQUA Lab equipment model 3TE Series 3B v 3.0 (Decagon Devices Inc. Washington, USA). The $\mathrm{pH}$ and water soluble solids were determined using five grams of bars homogenized with $45 \mathrm{~mL}$ of distilled water in a tissue homogenizer (Tecnal Turratec TE-102, Sao Paulo, Brazil) at 22,000 rpm for $1 \mathrm{~min}$ at $20{ }^{\circ} \mathrm{C}$. Then, the sample was filtered, and the filtrate was used for further analysis. The $\mathrm{pH}$ was directly measured on the filtrate with a pHmeter (Schott Handylab, London, UK), according to the AOAC methods (Association of Official Agricultural Chemists, 2010). The water soluble compounds (SS) were also quantified in the filtrate by refraction index using a digital refractometer (Reichert AR 200, Tokyo, Japan), with automatic temperature adjustment and the results were expressed in ${ }^{\circ} \mathrm{Brix}$, as described in AOAC methods (Association of Official Agricultural Chemists, 2010).

The chemical composition (moisture, lipids, proteins, crude fiber and ash) of snack bars was determined according to AOAC standard methods (Association of Official Agricultural
Chemists, 2010). Carbohydrates were determinated by difference, subtracting from $100 \mathrm{~g}$ the sum of protein, ash and lipids, and expressed in g/100 g. Minerals (calcium, phosphorous, iron, potassium) were quantified following AOAC methods. Total dietary fiber, soluble and insoluble fibers were determined by enzymatic-gravimetric AACC method (American Association of Cereal Chemists International, 2000), using the total dietary fiber assay kit (Sigma-Aldrich, St. Louis, MO, USA). The vitamin $\mathrm{C}$ was determined by colorimetric method using 2,4-dinitrophenylhydrazine, according to Strohecker \& Henning (1967). The absorbance was measured at $520 \mathrm{~nm}$ in spectrophotometer (Beckman 640B) and the results expressed in $\mathrm{mg}$ of ascorbic acidity/100 $\mathrm{g}$ snack bar. The antioxidant activity was estimated with the stable free radical 2, 2-diphenyl-1-picryl hydrazyl (DPPH), and the results expressed in percentage of free radical scavenging using the equation proposed by Souza et al. (2009).

\section{Sensory analysis}

Hedonic sensory evaluation of snack bars was conducted with 100 volunteer tasters, regular consumers of those products. Consumer test was carried out in the Sensory Analysis Laboratory of the Department of Food Science of University Federal of Lavras (Brazil) in individual booths. Snack bars were evaluated for appearance, aroma, taste, texture and overall acceptability on a nine-point hedonic scale, according to Meilgaard et al. (1991). Attributes were scored on a scale varying from " $9=$ like extremely" to " 1 = dislike extremely". Samples were presented in white plastic dishes coded with three-digit random numbers and served in a randomized order, in according with registration number on the ethics committee 20489913.0.0000.5148.

\section{Statistical analysis}

All the results were reported as means from three replicates, which were subjected to the analysis of variance (ANOVA) and Tukey's student range test $(\mathrm{p} \leq 0.05)$. All statistical were carried out using the software StatGraphics v. 5.1.

\section{Results and discussion}

The jerivá flour used in the experiment presented the following composition: $116.35 \mathrm{mg} .100 \mathrm{~g}^{-1}$ of vitamin C; $15.35 \mathrm{~g} .100 \mathrm{~g}^{-1}$ of total fiber; $0.29 \%$ of titratable acidity; $\mathrm{pH}$ of $4.96 ; 1.06 \%$ of lipid; $48.76^{\circ}$ Brix; 83.69 ppm of Fe and $0.17 \%$ of $\mathrm{Ca}$. Values showed by (Coimbra \& Jorge, 2011), in studies of proximate composition of palm fruits, revealed that the pulp of jerivá fruit is nutritionally rich, with $7.75 \%$ of moisture, $5.41 \%$ of protein, 3.21 of ash, 7.48 of lipids and 26.98 of total fibers.

Table 1 shows the effect of increasing levels (0 to 20\%) of jerivá flour on the proximate composition of the bars. The incorporation of jerivá flour reduced the moisture content and a progressive decrease in moisture was observed when up to $10 \%$ of flour was added (from $9.10 \mathrm{~g} .100 \mathrm{~g}^{-1}$ to $8.71 \mathrm{~g} .100 \mathrm{~g}^{-1}$ ). The same effect was observed in the lipid content, although in this case, a reduction resulted with increasing the level of jerivá flour. Conversely, in the bars containing 20\% of jerivá 
flour, the crude fiber content increased from $2.45 \mathrm{~g} .100 \mathrm{~g} \mathrm{~g}^{-1}$ to $4.12 \mathrm{~g} .100 \mathrm{~g}^{-1}$, proteins (from $6.12 \mathrm{~g} .100 \mathrm{~g}^{-1}$ to $7.12 \mathrm{~g} .100 \mathrm{~g}^{-1}$ ) and ash (from $1.80 \mathrm{~g} .100 \mathrm{~g}^{-1}$ to $2.10 \mathrm{~g} .100 \mathrm{~g} \mathrm{~g}^{-1}$ ). We found the following composition for the jeriva flour, which replaced the corn starch biscuit in the formulation of the bars, contained 9.99 g.100 g-1 moisture, 1.06 g. $100 \mathrm{~g}^{-1}$ lipids, 1.63 g. $100 \mathrm{~g} \mathrm{~g}^{-1}$ protein and $3.59 \mathrm{~g} .100 \mathrm{~g}^{-1}$ ash, which seems to positively affect the nutritional quality of the bars, by increasing the protein, fibers and ash content and reducing fats and carbohydrates. Higher values were presented by Coimbra \& Jorge (2011), 7.75\% moisture, $5.41 \%$ of protein, 3.21 of ash, 7.48 for lipids and 26.98 of total fibers. The difference found might be attributed to the soil and climatic conditions of each producing region, which can significantly influence the plant physiology and consequently the nutritional composition of the plant.

Dietary fiber (total, soluble and insoluble) increased depending on the concentration of jerivá flour (Table $2, \mathrm{P}<0.05$ ), similar to that observed for crude fiber. Dietary fiber was mostly insoluble, and the low content of soluble fiber was provided by the jerivá flour. According to Figuerola et al. (2005), the recommended ratio soluble/insoluble fiber for a healthy diet should be one to two. The ratio obtained in the supplemented bars was far below the recommended, which does not prevent the use of the jerivá bars as a source of fibers. In fact, the formulations CCO5\% CCO $10 \%$ and CCO15\%, according with World Health Organization \& Food and Agriculture Organization (2003), can be classified as food "source of fiber", because they presented a fiber content exceeding $3 \mathrm{~g} / 100 \mathrm{~g}$. Furthermore, the formulation $\mathrm{CCO} 20 \%$ can be classified as a food "rich in fiber", once the
Brazilian legislation requires a minimum of $6 \mathrm{~g}$ fiber $/ 100 \mathrm{~g}$ (for solids) for such labeling (World Health Organization \& Food and Agriculture Organization, 2003). Those levels of fibers are really promising for this type of product, particularly the CCO20\% bar, which showed a dietary fiber content 2.5 times higher than the values reported for commercial cereal bars (Sun Waterhouse et al., 2010). Once the fiber exerts a primary function in the human body and the consumption of high fiber foods has been associated to the prevention of chronic non-transmissible diseases (Becker et al., 2014; Harrington et al., 2001), the supplemented bars, especially the CCO20\%, might be considered as a very attractive ready-to-eat product to prevent such diseases.

Increases in the Vitamin $C$ content and antioxidant activity $(P<0.05)$ were observed in the supplemented bars (Table 2), as a result of the substitution of corn starch biscuit by jerivá flour in the formulations. Concerning the level of jerivá flour added, a steady increase in the vitamin C content was observed with the raise of the flour concentration. Therefore, the enriched food bars reiterate the high vitamin C content observed in the jerivá flour (116.35 mg.100 g $\mathrm{g}^{-1}$ ). Vitamin $\mathrm{C}$ is a potent antioxidant that effectively acts in the extinction of free radicals to prevent premature aging (Rosell, 2007). Simultaneously, an increase in the antioxidant activity was observed when jerivá flour was added. The increase in antioxidant activity can be associated to the enrichment of bars with vitamin C.

No significant difference was detected $(P<0.05)$ for the acidity values in the prepared formulations, and the average value of $0.26 \%$ was found for all the formulations of snack

Table 1. Proximate composition (g.100 g-1 wet weight basis) of snack bars supplemented with different concentrations of jeriva flour (CCO).

\begin{tabular}{|c|c|c|c|c|c|c|}
\hline \multicolumn{7}{|c|}{ Component $\left(\mathrm{g} .100 \mathrm{~g}^{-1}\right)$} \\
\hline Samples & Moisture & Fat & Crude Fiber & Protein & Ash & Carbohydrates \\
\hline Control & $9.10 \pm 0.16^{c *}$ & $2.11 \pm 0.02^{\mathrm{d}}$ & $2,45 \pm 0,28^{a}$ & $6.12 \pm 0.31^{\mathrm{a}}$ & $1.80 \pm 0.01^{\mathrm{a}}$ & $78.14 \pm 0.98^{\mathrm{d}}$ \\
\hline CCO $5 \%$ & $9.01 \pm 0.05^{\mathrm{b}}$ & $2.08 \pm 0.24^{\mathrm{d}}$ & $2.72 \pm 0.16^{\mathrm{b}}$ & $6.81 \pm 0.31^{b}$ & $1.82 \pm 0.01^{\mathrm{a}}$ & $77.56 \pm 0.37^{\mathrm{cd}}$ \\
\hline CCO 10\% & $8.72 \pm 0.03^{\mathrm{a}}$ & $2.00 \pm 0.03^{c}$ & $3.45 \pm 0.02^{c}$ & $6.81 \pm 0.9^{b}$ & $1.83 \pm 0.05^{\mathrm{a}}$ & $77.19 \pm 3.72^{c}$ \\
\hline CCO $15 \%$ & $8.74 \pm 0.03^{\mathrm{a}}$ & $1.85 \pm 0.19^{\mathrm{b}}$ & $3.42 \pm 0.21^{\mathrm{c}}$ & $7.01 \pm 0.14^{\mathrm{c}}$ & $1.97 \pm 0.08^{b}$ & $77.01 \pm 4.33^{\mathrm{b}}$ \\
\hline CCO $20 \%$ & $8.71 \pm 0.21^{\mathrm{a}}$ & $1.76 \pm 0.06^{\mathrm{a}}$ & $4.12 \pm 0.22^{\mathrm{d}}$ & $7.12 \pm 0.81^{\mathrm{c}}$ & $2.10 \pm 0.09^{c}$ & $76.19 \pm 0.73^{\mathrm{a}}$ \\
\hline Average & 8.85 & 1.96 & 3.23 & 6.77 & 1.90 & 77.27 \\
\hline Stand.Desv. & 0.22 & 0.13 & 0.26 & 0.96 & 0.07 & 1.19 \\
\hline
\end{tabular}

*Values followed by different letters within columns indicate significant differences $(P \leq 0.05)$.

Table 2. Dietary fiber composition, vitamin C and antioxidant activity (dry weight basis) of snack bars supplemented with jerivá flour (CCO).

\begin{tabular}{|c|c|c|c|c|c|}
\hline Samples & $\begin{array}{l}\text { Ins. Fiber } \\
\left(\mathrm{g} .100 \mathrm{~g}^{-1}\right)\end{array}$ & $\begin{array}{l}\text { Sol. Fiber } \\
\left(\mathrm{g} .100 \mathrm{~g}^{-1}\right)\end{array}$ & $\begin{array}{l}\text { Tot. Fiber } \\
\left(\mathrm{g} .100 \mathrm{~g}^{-1}\right)\end{array}$ & $\begin{array}{c}\text { Vitamin C } \\
\left(\mathrm{mg}^{-\mathrm{g}^{-1}}\right)\end{array}$ & $\%$ Scav. free radicals \\
\hline Control & $2.71 \pm 0.37^{\mathrm{a}}$ & $0.002 \pm 0.001^{\mathrm{a}}$ & $2.71 \pm 0.35^{\mathrm{a}}$ & $34.36 \pm 1.20^{\mathrm{a}}$ & $5.13 \pm 0.20^{\mathrm{a}}$ \\
\hline CCO $5 \%$ & $4.67 \pm 0.06^{\mathrm{b}}$ & $0.003 \pm 0.002^{\mathrm{a}}$ & $4.68 \pm 0.06^{b}$ & $35.31 \pm 0.95^{\mathrm{ab}}$ & $5.26 \pm 0.40^{\mathrm{a}}$ \\
\hline CCO 10\% & $5.00 \pm 0.12^{\mathrm{b}}$ & $0.003 \pm 0.001^{\mathrm{a}}$ & $5.00 \pm 0.13^{\mathrm{b}}$ & $37.45 \pm 3.50^{\mathrm{b}}$ & $5.36 \pm 0.35^{\mathrm{a}}$ \\
\hline CCO 15\% & $5.53 \pm 0.23^{c}$ & $0.007 \pm 0.001^{\mathrm{b}}$ & $5.54 \pm 0.22^{c}$ & $38.82 \pm 1.50^{c}$ & $5.77 \pm 1.23^{\mathrm{b}}$ \\
\hline CCO $20 \%$ & $6.65 \pm 0.06^{\mathrm{d}}$ & $0.010 \pm 0.001^{\mathrm{c}}$ & $6.66 \pm 0.06^{\mathrm{d}}$ & $40.81 \pm 1.15^{\mathrm{d}}$ & $6.33 \pm 1.87^{c}$ \\
\hline Average & 4.91 & 0.020 & 4.91 & 37.50 & 5.57 \\
\hline Stand.Desv. & 0.24 & 0.000 & 0.24 & 1.52 & 0.88 \\
\hline
\end{tabular}

*Values followed by different letters within columns indicate significant differences $(P \leq 0.05)$; TDF: total dietary fiber; IDF: insoluble dietary fiber; SDF: soluble dietary fiber. AP: antioxidant potential expressed as the discoloration of the DPPH radical/100 $\mathrm{mL}$. 
bars. In relation to the $\mathrm{pH}$, a significant decrease was observed in the CCO20\% (6.78) compared to control samples (6.92), such decrease can result from the low $\mathrm{pH}$ of jerivá flour (4.96) (Table 3). Similar behavior was observed for the soluble solids, which reduced from $85.44^{\circ} \mathrm{Brix}$ to $76.22^{\circ} \mathrm{Brix}$, and water activity (Aw), decreasing from 0.56 to 0.53 , in control and CCO $20 \%$, respectively. Lower values of soluble solids and water activity might be associated with the decrease in the carbohydrate fraction (Table 1). Hogan et al. (2012), analyzing cereal bars with high protein, found higher Aw values, compared to those observed in the present study. Nevertheless, the decrease in Aw (Table 3) and in moisture (Table 1) with higher proportion of jerivá flour enhances the microbiological stability of the bars by lowering the growth of spoilage microorganisms. Microbial growth is favored at Aw greater than or equal to

Table 3. Physico-chemical characteristics of the snack bars supplemented with jerivá flour (CCO).

\begin{tabular}{lccc}
\hline \multicolumn{1}{c}{ Samples } & $\mathbf{p H}$ & SS ( ${ }^{\circ}$ Brix $)$ & Aw \\
\hline Control & $6.92 \pm 0.01^{\mathrm{d} *}$ & $85.44 \pm 0.33^{\mathrm{c}}$ & $0.56 \pm 0.01^{\mathrm{c}}$ \\
CCO 5\% & $6.91 \pm 0.01^{\mathrm{d}}$ & $82.86 \pm 1.65^{\mathrm{bc}}$ & $0.55 \pm 0.01^{\mathrm{b}}$ \\
CCO 10\% & $6.88 \pm 0.02^{\mathrm{c}}$ & $79.52 \pm 1.76^{\mathrm{b}}$ & $0.53 \pm 0.01^{\mathrm{a}}$ \\
CCO 15\% & $6.84 \pm 0.02^{\mathrm{b}}$ & $79.56 \pm 1.38^{\mathrm{b}}$ & $0.53 \pm 0.01^{\mathrm{a}}$ \\
CCO 20\% & $6.78 \pm 0.02^{\mathrm{a}}$ & $76.22 \pm 1.20^{\mathrm{a}}$ & $0.53 \pm 0.01^{\mathrm{a}}$ \\
Average & $\mathbf{6 . 8 6}$ & $\mathbf{8 0 . 7 2}$ & $\mathbf{0 . 5 9}$ \\
Stand.Desv. & $\mathbf{0 . 0 4}$ & $\mathbf{1 . 6 7}$ & $\mathbf{0 . 0 0}$ \\
\hline
\end{tabular}

${ }^{*}$ Values followed by different letters within columns indicate significant differences $(P \leq 0.05)$.
0.6 (Scott, 1957; Brooker et al., 1992). Therefore, it should be expected long shelf life of the developed bars and even longer in the supplemented bars.

The supplemented bars showed significant amounts of phosphorus, potassium, zinc, manganese and iron in relation to the control (Table 4), and the mineral content increased with the level of supplementation. Copper, manganese and iron levels significantly increased when the bars were supplemented with $10 \%, 15 \%$ or $20 \%$ of jerivá flour. Micronutrients are compounds necessary for proper physiological condition of the body which can be orally administered in enteral or parenteral diet, and are required to maintain a proper balance of nutrients (Davidi et al., 2011; Sriram \& Lonchyna, 2009). Because minerals cannot be synthesized, they should be supplied from food, and considering the mineral deficiencies worldwide, the bars developed with jerivá flour can be considered as viable alternatives for mineral intake.

The scores given by the panelists to the cereal bar formulations, for sensorial preference are shown in Table 5. No significant differences were observed among the formulations for any of the attributes evaluated. CCO10\% CCO15\% and CCO $20 \%$ supplemented bars received the highest averages for appearance, whereas the formulations CCO5\%, CCO10\% showed higher scores for the attributes flavor and texture. Therefore, the partial substitution of corn starch biscuit by jerivá flour improved the sensory acceptability of the food bars. The scores obtained for the supplemented bars were higher than those reported for other nutritious bars (Bower \& Whitten, 2000; Silva et al., 2014; Rosell, 2007).

Table 4. Effect of the addition of jerivá flour on the mineral content of supplemented snack bars (CCO).

\begin{tabular}{|c|c|c|c|c|c|c|c|c|}
\hline & \multicolumn{4}{|c|}{ Minerals (g.100 g $\left.{ }^{-1}\right)$} & \multicolumn{4}{|c|}{ (mg.kg-1) } \\
\hline & $\mathbf{P}$ & $\mathbf{K}$ & $\mathrm{Ca}$ & $\mathrm{Mg}$ & $\mathrm{Cu}$ & Mn & Zn & $\mathrm{Fe}$ \\
\hline \multicolumn{9}{|l|}{ Samples } \\
\hline Control & $0.14 \pm 0.01^{\mathrm{a} \star}$ & $0.183 \pm 0.01^{\mathrm{a}}$ & $0.70 \pm 0.11^{\mathrm{a}}$ & $0.02 \pm 0.01^{\mathrm{a}}$ & $1.07 \pm 0.01^{\mathrm{a}}$ & $3.56 \pm 0.89^{\mathrm{a}}$ & $13.52 \pm 0.51^{\mathrm{a}}$ & $24.20 \pm 0.85^{\mathrm{a}}$ \\
\hline CCO $5 \%$ & $0.15 \pm 0.02^{\mathrm{ab}}$ & $0.203 \pm 0.02^{\mathrm{b}}$ & $0.76 \pm 0.13^{\mathrm{b}}$ & $0.03 \pm 0.01^{\mathrm{a}}$ & $1.08 \pm 0.02^{\mathrm{a}}$ & $7.04 \pm 0.91^{b}$ & $14.73 \pm 0.53^{\mathrm{b}}$ & $26.69 \pm 1.11^{\mathrm{b}}$ \\
\hline CCO 10\% & $0.16 \pm 0.02^{\mathrm{b}}$ & $0.28 \pm 0.01^{c}$ & $1.52 \pm 0.21^{c}$ & $0.24 \pm 0.01^{\mathrm{b}}$ & $1.13 \pm 0.03^{\mathrm{b}}$ & $7.59 \pm 0.81^{c}$ & $14.80 \pm 0.49^{\mathrm{b}}$ & $28.06 \pm 1.05^{\mathrm{c}}$ \\
\hline CCO 15\% & $0.18 \pm 0.02^{c}$ & $0.29 \pm 0.02^{c}$ & $1.48 \pm 0.11^{\mathrm{d}}$ & $0.25 \pm 0.01^{\mathrm{b}}$ & $1.44 \pm 0.03^{c}$ & $7.97 \pm 0.75^{\mathrm{d}}$ & $15.06 \pm 0.55^{\mathrm{c}}$ & $29.37 \pm 1.02^{\mathrm{d}}$ \\
\hline Desv.Stand. & 0.01 & 0.05 & 0.42 & 0.08 & 3.58 & 1.68 & 1.16 & 8.24 \\
\hline
\end{tabular}

${ }^{*}$ Values followed by different letters within columns indicate significant differences $(P \leq 0.05)$.

Table 5. Sensory evaluation of the snack bars supplemented with with different concentrations of jerivá flour (CCO).

\begin{tabular}{lccccc}
\hline \multicolumn{1}{c}{ Samples } & Appearance & Aroma & Taste & Texture & Overall Acceptance \\
\hline Control & 6.98 & 7.05 & 7.18 & 7.14 & 7.08 \\
CCO 5\% & 7.05 & 6.91 & 7.31 & 7.52 & 7.18 \\
CCO 10\% & 7.38 & 7.18 & 7.21 & 7.44 & 7.25 \\
CCO 15\% & 7.28 & 7.01 & 7.01 & 7.21 & 7.11 \\
CCO 20\% & 7.41 & 7.02 & 6.78 & 7.28 & 7.11 \\
Average & 7.22 & 7.03 & 7.09 & $\mathbf{1 . 3 9}$ & \\
Desv.Stand. & $\mathbf{0 . 4 7}$ & $\mathbf{0 . 0 9 7}$ & $\mathbf{0 . 2 1}$ & & \\
\hline
\end{tabular}

Not observed significant differences between the averages using Tukey's student range test $(\mathrm{p} \leq 0.05)$. 


\section{Conclusion}

Snack bars incorporated with $20 \%$ of jerivá flour showed minor changes in physicochemical properties and sensory perception. Nutritionally important compounds, such as total dietary fiber, vitamin $\mathrm{C}$, mineral contents and the antioxidant activity significantly increased. Besides the beneficial nutritional effects, the addition of up to $20 \%$ jerivá flour improved the quality of the snack bars by increasing the contents of ash, fats, total fibers and vitamin C.

\section{Acknowledgements}

Authors thank the financial support of CAPES; FAPEMIG, CNPq, Spanish Scientific Research Council (CSIC) and the Generalitat Valenciana (Project Prometeo 2012/064). EP da Silva would like to thank for the doctoral scholarship by the Federal University of Lavras (Lavras, Minas Gerais state, Brazil).

\section{References}

American Association of Cereal Chemists International - AACC. (2000). International approved methods (11th ed.). St Paul: AACC.

Association of Official Agricultural Chemists - AOAC. (2010). International approved methods (1094 p.). Washington: AOAC.

Becker, F. S., Damiani, C., De Melo, A. A. M., Borges, P. R. S., \& Vilas Boas, E. V. B. (2014). Incorporation of Buriti Endocarp Flour in Gluten-free Whole Cookies as Potential Source of Dietary Fiber. Plant Foods for Human Nutrition (Dordrecht, Netherlands), 69(4), 1-6. http://dx.doi.org/10.1007/s11130-014-0440-y. PMid:25315266.

Bower, J. A., \& Whitten, R. (2000). Sensory characteristics and consumer linking for cereal bar snack foods. Journal of Sensory Studies, 15(3), 327-345. http://dx.doi.org/10.1111/j.1745-459X.2000.tb00274.x.

Brooker, D. B., Bakker-Arkema, F. W., \& Hall, C. W. (1992). Drying and storage of grains and oil seeds. Westport: The AVI Publishing Company.

Coimbra, M. C., \& Jorge, N. (2011). Proximate composition of guariroba (Syagrus oleracea), jerivá (Syagrus romanzoffiana) and macaúba (Acrocomia aculeata) palm fruits. Food Research International, 44(7), 2139-2142. http://dx.doi.org/10.1016/j.foodres.2011.03.032.

Davidi, A., Reynolds, J., Njike, V. Y., Ma, Y., Doughty, K., \& Katz, D. L. (2011). The effect of the addition of daily fruit and nut bars to diet on weight, and cardiac risk profile, in overweight adults. Journal of Human Nutrition and Dietetics, 24(6), 543-551. http://dx.doi. org/10.1111/j.1365-277X.2011.01201.x. PMid:21883530.

Figuerola, F., Hurtado, M. L., Estévez, A. M., Chiffelle, I., \& Asenjo, F. (2005). Fiber concentrates from Apple pomace and citrus peel as potential fibers sources for food enrichment. Food Chemistry, 91(3), 395-401. http://dx.doi.org/10.1016/j.foodchem.2004.04.036.
Harrington, M. E., Flynn, A., \& Cashman, K. D. (2001). Effects of dietary fiber extracts on calcium absorption in the rat. Food Chemistry, 73(3), 263-269. http://dx.doi.org/10.1016/S0308-8146(00)00296-X.

Hogan, A. S., Chaurin, V., O’Kennedy, B. T., \& Kelly, M. P. (2012). Influence of dairy proteins on textural changes in high-protein bars. International Dairy Journal, 1-8. http://dx.doi.org/10.1016/j. dairyj.2012.02.006.

Izzo, M., \& Niness, K. (2001). Formulating nutrition bars with inulin and oligofructose. Cereal Foods World, 46, 102-105.

Lin, P. H., Miwa, S., Li, Y. J., Wang, Y., Levy, E., Lastor, K., \& Champagne, C. (2010). Factors influencing dietary protein sources in the premier trial population. Journal of the American Dietetic Association, 110(2), 291-295. http://dx.doi.org/10.1016/j.jada.2009.10.041. PMid:20102859.

Meilgaard, M., Civille, G. V., \& Carr, B. T. (1991). Sensory evaluation techniques (2nd ed., pp. 354). Florida: CRC Press.

Norajit, K., Gu, B.-J., \& Ryu, G.-H. (2011). Effects of the addition of hemp powder on the physicochemical properties and energy bar qualities of extruded rice. Food Chemistry, 129(4), 1919-1925. http:// dx.doi.org/10.1016/j.foodchem.2011.06.002.

Rosell, C. M. (2007). Vitamin and mineral fortification of bread. In B. Hamaker (Eds.), Technology of functional cereal products (pp. 336361). Cambridge: Woodhead Publishing Ltd.

Scott, W. J. (1957). Water relations of food spoilage microorganisms. Advances in Food Research, 7(9), 83-127. http://dx.doi.org/10.1016/ S0065-2628(08)60247-5.

Silva, E. P., Siqueira, H. H., Lago, R. C., \& Rosell, C. M. (2014). Developing fruit-based nutritious snack bars. Journal of the Science of Food and Agriculture, 94(1), 52-56. http://dx.doi.org/10.1002/ jsfa.6282. PMid:23794383.

Souza, C. R. F., Georgetti, S. R., Salvador, M. J., Fonseca, M. J. V. F., \& Oliveira, W. P. O. (2009). Antioxidant activity and physical-chemical properties of spray and spouted bed dried extracts of Bauhinia forficata. Brazilian Journal of Pharmaceutical Sciences, 45(2). http:// dx.doi.org/10.1590/S1984-82502009000200004.

Sriram, K., \& Lonchyna, V. A. (2009). Micronutrient supplementation in adult nutrition therapy: practical considerations. Journal of Parenteral and Enteral Nutrition, 33(5), 548-562. http://dx.doi. org/10.1177/0148607108328470. PMid:19454751.

Strohecker, R. L., \& Henning, H. M. (1967). Analysis of vitamins: proven methods (428 p.). Madri: Paz Montalvo.

Sun-Waterhouse, D., Teoh, A., Masssarotto, C., Wibisono, R., \& Wadwa, S. (2010). Comparative analysis of fruit-based functional snack bars. Food Chemistry, 119(4), 1369-1379. http://dx.doi.org/10.1016/j. foodchem.2009.09.016.

World Health Organization - WHO, \& Food and Agriculture Organization - FAO. (2003). Diet, nutrition and the prevention of chronic diseases (Technical Report Series, No. 916). Geneva: WHO/FAO. 